\title{
НАУКОВА РЕЦЕНЗІЯ
}

\author{
Visn. Lviv. Univ., Ser. Zhurn. 2021: 50; 240-248 • DOI: http://dx.doi.org/10.30970/vjo.2021.50.11115
}

УДК 070(410=161.2-054.72):001-051(477)М.Тимошик

\section{УКРАЇНСЬКА ЖУРНАЛІСТИКА У ВЕЛИКІЙ БРИТАНІЇ}

\author{
Мар'ян Житарюк \\ Львівський національний університет імені Івана Франка \\ вул. Генерала Чупринки, 49, 79044, Львів, Украӥна \\ e-mail: maryan.zhytaryuk@lnu.edu.ua \\ https://orcid.org/0000-0002-5690-5701
}

У рецензії професора Мар’яна Житарюка йдеться про книжкову наукову новинку монографію професора Миколи Тимошика «Українська журналістика в діаспорі: Велика Британія. Монографія. К.: Наша культура і наука, 2021. 512 с. - іл., ім. та предм. пок., резюме англ., нім. м.».

Відомий вчений-журналістикознавець, професор М. С. Тимошик, написав грунтовну працю, яка, за наповненням і змістом, є поєднанням монографії, навчального посібника та наукового нарису. Ця книжка може бути корисна і студентові, і журналістові-практикові чи будь-кому, кого цікавить історія української діаспори, української журналістики та української культури.

Автор присвятив свою працю Степанові Ярмусю з канадського Вінніпега - протопресвітерові, журналістові, редакторові, професорові. Епіграфом до книжки стали слова Івана Багряного: «...Наша преса, народжена під Дамоклевим мечем репатріації..., не тільки вистояла і вціліла донині, а й виявила блискучу здібність рости й розвиватися... I цим поставлено дійсно непроминальний приклад - як «голота», що прийшла на Захід без гроша за душею, може та вміє діяти так організовано; в якій мірі сучасна «збільшовичена» та «зденаціоналізована» окупантом людина здібна до збірної масової акції».

Ключові слова: Микола Тимошик, українська журналістика у Великій Британії, друкована преса, радійна преса, місія українського журналіста на чужині.

У вступній частині «Від автора» Микола Тимошик висловився про чин служіння національній ідеї у Слові: «Саме таке Слово - народжене в муках і мріях, уречевлене у різний час, різними способами, системно розмножуване й поширюване коштом самих емігрантів на десятках тисяч сторінок газетних, журнальних і книжкових видань, як голос поневоленої, але нескореної України, - віддавна притягувало мене і як дослідника, і як журналіста, і як письменника. Нове професійне захоплення згодом утілилося в окремий корпус книжок і наукових та публіцистичних статей, яке відважуюся віднести до власної діаспоріани» (С. 11). I це не перебільшення. У

(C) Житарюк М., 2021 

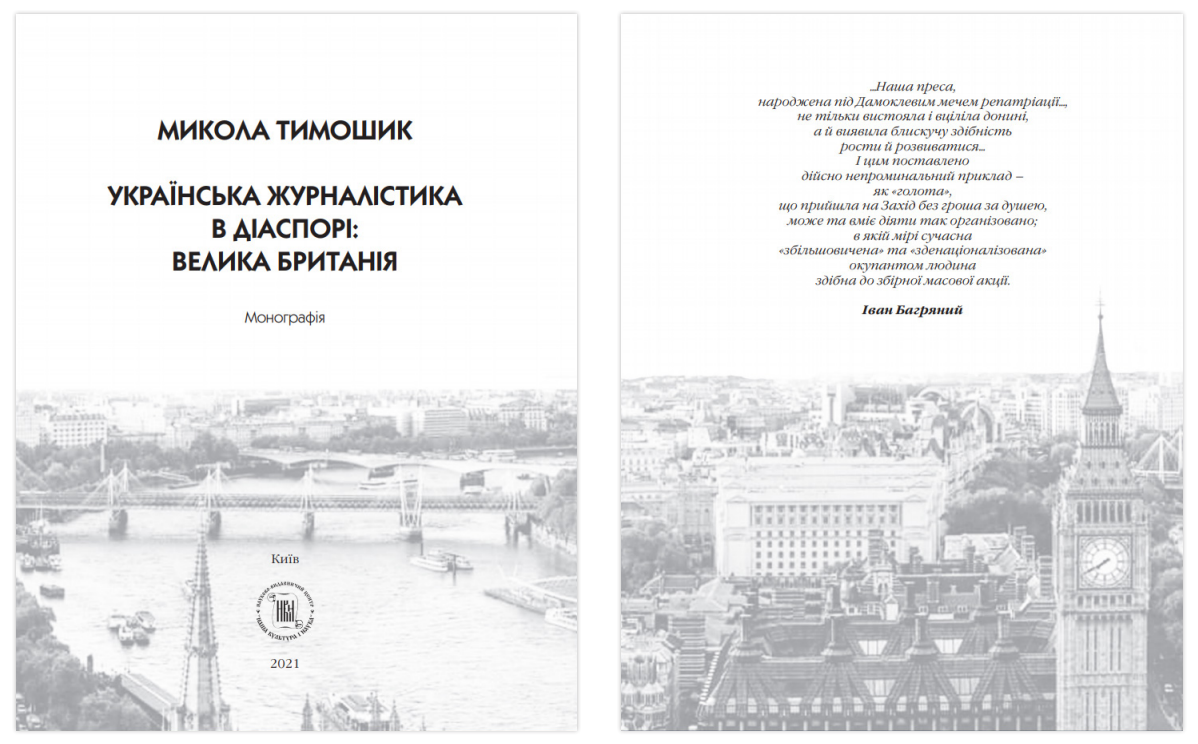

професора Тимошика справді великий послужний список таких праць. Це і «Голгофа Івана Огієнка», $\mathrm{i}$ «Лишусь навіки з чужиною...», i «Запізніле вороття» (станом на осінь 2020 р., з упорядкуванням, передмовами та примітками М. Тимошика, побачив світ 21 том цього проєкту), й «Історія видавничої справи» (підручник для студентів університетів, що базується на новому, переважно архівному, матеріалі, здебільшого невідомого читачеві), й «Українська книга і преса в Італії» (2015) та науково-популярна оповідь «Українська книга і світ» (спільне видання Київського національного університету культури і мистецтв та Українського університету у Вашингтоні (2018). І ось тепер на суд науковцеві, студентові, журналістові, історикові, кожному, кого цікавить національна історія, представлено «в новому двокнижжі результати недавніх пошуків історій і фактів про те, як жили і працювати, що залишили по собі невеликі гурти українських мрійників і однодумців - творців українського пресового та книговидавничого руху на теренах Великої Британії» (С. 13).

Відомо, що перші спроби осмислити саме явище української еміграції до Великої Британії з'являються у 30-40-і pp. - безпосередньо в українських бюлетенях, газетах та календарях, які видавали тут українці і англійською, і українською мовами. Про це йдеться, зокрема, у таких розвідках: Воропай О. В дорозі на Захід: Щоденник втікача. Лондон: Українська Видавнича Спілка, 1970. 246-247 с.; Українське бюро в Лондоні: Короткий звіт його діяльності (Машинопис). The Polish Institute and Sikorski Muzeum: Kol. 433/2. Biura Ukrainskie: Zalozenia I Spravozdania. 1931-1939. Strony 22-26; 13 Вільховий Павло. Українська громада в Манчестер. Наш клич. 1946. Ч. 7. 30 трав. Натомість Микола Тимошик у своїй книзі зазначає: «...в історії українців Великобританії $є$ чітко окреслені кілька епізодів, які дають підстави перенести часові межі присутності наших земляків на цих теренах значно раніше. I не лише присутності, а й активної участі і в матеріальній (заробітковій), і в культурно-духовній та інформаційній сферах». Далі проф. М. С. Тимошик пропонує на суд читачеві нову хронологію (С. 21-26): 
1) 1902-1908 pр. Заснування в Манчестері першої української колонії. Облаштування Українського дому - з капличкою, читальнею, буфетом для своїх. Згодом, через три-чотири десятиліття, такі Українські доми постали і в інших містах Англії, і в Шотландії, й у Валлії;

2) 1919-1921 pр. Діяльність Української дипломатичної місії в Лондоні, яка репрезентувала уряд Української Народної Республіки.

3) 1930-1939 роки. Діяльність у столиці Великобританії Українського пресового бюро. Засновником і спонсором цього специфічного інформаційного українського осередку став виходець із Галичини Яків Макогін.

4) 1940-1947 pр. Пожвавлення темпів, масштабів та змістового наповнення організованого життя українців на британських островах. М. Тимошик називає три великі групи українських емігрантів, кожна з яких формувалася за різних обставин. Крім успіхів української преси в діаспорі, яким головно і присвячено наукове дослідження, М. С. Тимошик з болем говорить і про самокритиканство та самопоїдання на чужині у вигляді «газетних воєн», які стали результатом міжособистісних, міжгрупових і міжпартійних стосунків. Цій проблемі й була присвячена редакційна стаття «Надуживання преси» (Українська Думка. 1949. 9 лип.). Аналіз цієї публікації, як і низки інших на таку ж тему, дав змогу дослідникові виокремити головні ознаки цього ганебного явища. Наприклад, це, по-перше, «конче когось вдарити» ніби неписане правило для публіцистів, що писали на громадсько-політичні теми, по-друге, «приперченість» газетно-брошурної лектури, яку охоче споживав не вироблений політично український загал, по-третє, - надмірна гострота та памфлетизм, пасквільщина, інакше газету вважали нудною, по-четверте, войовнича міжтаборовість, що дуже компрометувала не тільки самі табори, а насамперед - Україну.

На основі ретроспективи феномена журналістської роботи, автор осмислює й узагальнює життя українців. Становлення, здобутки й проблеми головних редакційних осередків подано за хронологією і певними напрямами, себто видами журналістики: агенційна, газетна, журнальна та радійна. Акцентовано також на тому, яка місія і яке кредо українського журналіста за кордоном (розділ 1). У книзі висвітлено аспекти й англомовної періодики. У розділі 2 йдеться про пресове бюро як вид агенційної журналістики, у розділі 3 - про газетну журналістику, зокрема: «Наш Клич», «Український Клич», «Українську Думку» та ін. Розділ 4 присвячено журнальній періодиці, зокрема проаналізовано такі видання: «Голос Молоді», «Визвольний Шлях», «Авангард», «Юні друзі», «Сурмач», «Наша Церква», «Відомості єпархіального Управління УАПЦ у Великій Британії». У розділі 5 йдеться про радійну журналістику, зокрема ВВС та «Голос Америки». Розділ 6 присвячено англомовній українській пресі у Великій Британії: «The Ukraine», «Ukrainian Bureau Bulletin», «Ukrainian Bulletin», «Refugee» - «Refugee New», «The Ukrainian Review».

Книжка М. С. Тимошика добре ілюстрована: крім текстового контенту, подано графічні матеріали, переважно титульні аркуші українських періодичних видань у Великій Британії. Це дає змогу читачеві відтворити атмосферу і стиль часу.

Думаю, що резонно відтворити зміст монографії докладніше.

У розділі 1 - «Місія і кредо українського журналіста на чужині» - проф. Микола Тимошик докладно зупиняється на специфіці пресового руху на чужині, говорить

1 Тимошик, Микола (2021), Українська журналістика в діаспорі..., с. 27-72. 
про відповідальність за слово і за дії, в т. ч. - й войовничі дії між собою, зупиняється на започаткуванні стандартів національної журналістики, акцентує на головних завданнях преси з урахуванням поняття моралі в журналістиці, виокремлює уроки на майбутнє, аналізує проблему журналістських кадрів і показує спроби їі розв’язання.

«В українські діаспорній періодиці раз-по-раз з’являлися спорадичні публікації про необхідність заснування спеціального навчального закладу, де б готувалися кадри для преси, - читаємо в монографії. - Скажімо, цю тему постійно порушувано на сторінках «Українського Журналіста» - бюлетеня Федерації Спілок Українських Журналістів Америки і Канади. А одна із проблемних статей цього видання так i називалася «За катедру журналістики при УВУ»². «Одним із важливих завдань, наголошується в ній, - є саме виховання професійних кадрів, які згодом займуть найвідповідальніші посади редакторів української преси»3.

Далі в підрозділі «Проєкт катедри журналістики при УВУ в Мюнхені» докладно розписано історію зародження ідеї центру підготовки журналістських кадрів та iii реалізації у Мюнхені. Виявляється, перші спроби започаткувати курси з вивчення журналістики після Другої світової війни були зроблені не в Українському Вільному Університеті (УВУ), який 1945 року переїхав із Праги до Мюнхена, а в Українському Технічно-Господарському Інституті (УТГІ), який також був переміщений із чеських Подєбрад до Регенсбурга. М. Тимошик навіть подає фотокопію видання циклостилевим способом машинописного курсу з 15-ти лекцій А. Животка «Історія української преси» (1946), на якій чітко видно назву саме цього Інституту4. У Високій школі державних наук (ВШДН), відкритій при УТГІ, в ухвалених «Правилах, програмах та плянах навчання» перед курсами журналістики були поставлені такі завдання: «Дати науково-теоретичні знання, необхідні українським діячам в їх громадській і журналістичній чинності, уможливити поповнення фахових і загальних теоретичних знань для наших практичних журналістів, а також підготовити нові кадри молодих українських працівників для практичної діяльности на полі журналістики й національно-суспільного життя ${ }^{5}$. Хотілося б, щоб, попри засилля формування компетентнісних характеристик і навиків, таким речам приділяли увагу в нормативних документах сьогодні. Програмою ВШДН передбачено було вивчення й «Основ журналізму». Тут стали в пригоді тексти лекцій професора Степана Сірополка, які він написав 1940 р. у Празі, але видані вони були засобами малої поліграфії вже в Регенсбурзі ${ }^{6}$. Курс лекцій з історії української журналістики, крім Аркадія Животка, підготував, але не встиг видати, професор Ольгерд Бочковський. Ці дисципліни і були основними, стрижневими у підготуванні українських патріотичних журналістських кадрів у діаспорі. Повинні погодитися і з думкою проф. Тимошика про те, що ці

\footnotetext{
Там само, с. 50

3 Цит. за: Шуль, Андрій (1972), «За катедру журналістики при УВУ», Український журналіст. Ч. 9 , c. $38-39$.

4 Тимошик, Микола (2021), Українська журналістика в діаспорі..., с. 51.

5 Ніщеменко, К., Зозуля, Я. (1947), Правила, програми та пляни навчання, Регенсбург, 1947, с. 110. У кн.: Тимошик Микола (2021), Украӥнська журналістика в діаспорі... С. 52.

6 Сірополко, Степан (1946), Основи журналізму. Курс лекції, Регенсбург, 57 с.
} 
тексти не втратили своєї актуальності й пізніше. Наприклад, праця А. Животка вже двічі перевидана - у Мюнхені ${ }^{7}$ і в Києві ${ }^{8}$.

Осібно постає проблема Спілки Українських Журналістів на чужині. Але через те, що у Великій Британії українських журналістів замало для створення спілки журналістів, вистачало хіба що на філію СУЖ, у грудні 1948 р. в Лондоні було створено Товариство Українських Письменників і Журналістів (ТУПіЖ) при Союзі Українців у Великій Британії. Коли можливості ТУПіЖу ослабли і практично були вичерпані, активна група українських журналістів і з боку Союзу Українців Великобританії (СУБ), й Української Видавничої Спілки (УВС) вирішила започаткувати нову журналістську організацію. У січні 1963 р. в Лондоні постало Товариство Українських Вільних Журналістів (ТУВЖ).

Розділ 2 - «Пресове бюро як вид агенційної журналістики» (с. 73-146) - знайомить читача 3 першими українськими дипломатами і журналістами в Лондоні, 3 постанням Українського пресового бюро в Лондоні (1931-1939рр.), розповідає про специфіку діяльності прес-бюро на чужині та згортання його діяльності.

3 монографії М. Тимошика ми довідуємось, що Українське пресове бюро в Лондоні розпочало діяльність у березні 1931 року. Започаткував його колишній емігрант iз Галичини, громадянин США Яків Макогін. Згодом було відкрито філії в Женеві і Празі. «Бюро виконувало роль своєрідного українського посольства, головною метою якого було ознайомлення західного світу із нерозв'язаним «українським питанням». Основні напрямки діяльности: інформаційно-видавнича; співпраця з іноземними журналістами; співпраця з британськими парламентарями; благодійні проєкти, спрямовані на захист зарубіжного українства. Припинило діяльність у травні 1940 року»'.

Під час наукового стажування у Великій Британії 2016 року Миколі Тимошику першому з числа українських та зарубіжних дослідників емігрантської преси вдалося не лише натрапити на сліди архіву Українського пресового бюро в Лондоні, а й опрацювати його. Парадоксальність такої знахідки в тому, що теки із документами цього архіву пролежали без руху майже 80 років не у відомій бібліотеці чи архіві Великої Британії, а в... приватному польському інституті, що має назву «Polish Institute and Sikorski Museum in London» (Польський Інститут і музей ім. Сікорського у Лондоні). М. Тимошик також встановив, що «колекція українських документів в Архіві Сікорського в Лондоні зберігається під числом 433 і розміщена в більш ніж півтори сотні різних за кількістю сторінок теках (обсяг кожної теки - від 20 до 200 сторінок). Рукописні та друковані на машинці документи, що мають відношення до історії створення й діяльності Бюро (довідки, звіти, огляди, відозви, звернення, офіційне листування, фотографії) охоплюють 127 сторінок. Ця тека має назву: Biura Ukraińskie: założenia i Sprawozdania z Działalności. 1931-1939. Kolekcja 433/2. Strony $1-107+\operatorname{str} 108-127\rangle^{10}$.

\footnotetext{
Животко, Аркадій (1989-90), Історія української преси, Український Технічно-Господарський Інститут, Мюнхен, 334 с.

8 Животко, Аркадій (1999), Історія украӥнської преси (Упор., авт. передм. і приміт. М. Тимошик, Наша культура і наука, Київ, 362 с.

9 Тимошик, Микола (2021), Українська журналістика в діаспорі: Велика Британія, с. 90.

${ }^{10}$ Там само, с. 94.
} 


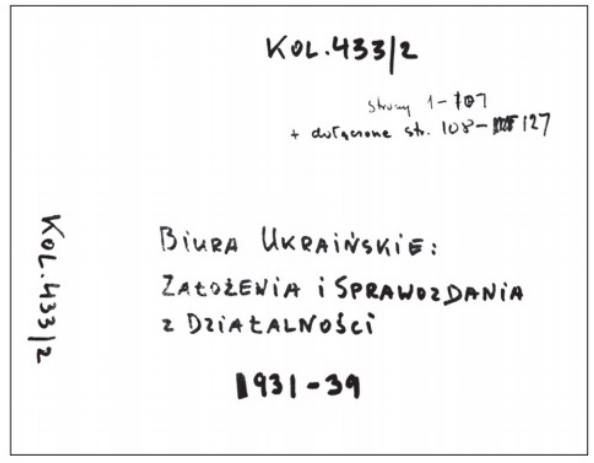

Титульна сторінка однієї із архівних тек

Рис. 3. Фотокопія ілюстрації архіву Украӥнського бюро в Лондоні ${ }^{11}$.

Як зазначає дослідник і автор монографії, найповніші в цих теках - листування з Євгеном Онацьким (60 сторінок) та Софією Русовою (56 сторінок). Але тут також збережено листи до УПБ і відповіді на них Михайла Грушевського, Свгена Коновальця, Володимира Кубійовича, Ісака Мазепи, Романа Смаль-Стоцького, Олени Кисілевської, Василя Королева-Старого, Юрія Пеленського, Ігоря Кедровського, Олександра Колесси, Млади Липовецької. Є тут і тека документів «Гетьман Скоропадський». Микола Тимошик навіть структурував архів за вісьмома критеріями:

1. Повні комплекти друкованої продукції, які Бюро випускало англійською i українською мовою: періодичні бюлетені, звідомлення для преси, вирізки з тодішніх українських і зарубіжних газет на українознавчу тематику.

2. Упорядковані працівниками бюро добірки матеріалів під назвами «Факти про Україну».

3. Підготовлений членом британського парламенту Реєм Дейвісом огляд про польсько-українські стосунки.

4. Матеріали про польсько-український конфлікт у Східній Галичині, підготовлений англійськими парламентарями Джеймсом Барром та Реєм Дейвісом.

5. Петиція до Ліги об’єднаних націй щодо ситуації з українцями у Польщі.

6. Огляд праці Українського бюро в Лондоні за роки 1931-1933, підготовлений управителем цієї установи Володимиром Кисілевським.

7. Текст листа-повідомлення про заснування Українського бюро в Лондоні, надісланий до редакцій іноземних та українських газет 5 квітня 1931 року.

8. Листування. Ця частина архіву поділена на кілька розділів: офіційне листування, листування $з$ фізичними особами, листування між відділеннями бюро в Женеві та Празі. Листи складені за алфавітом і в хронологічній послідовності. До кожного отриманого листа прикріплена копія відповіді. 3-поміж цінних документів - оригінали листів Свгена Онацького, Софії Русової ${ }^{12}$.

Увесь цей масив досі невідомих нікому архівних документів і є основою другого розділу монографії, в якому міститься докладний аналіз документів, статей,

\footnotetext{
${ }_{11}$ Там само

12 Тимошик, Микола (2021), Українська журналістика в діаспорі: Велика Британія, с. 96.
} 
особливостей створення і Українського пресово бюро, і багатьох україномовних та англомовних видань у Великобританії.

Щоб тримати інтригу і не розкривати зміст дуже поважного видання на понад 500 сторінок, ми не будемо детально описувати зміст монографії М. С. Тимошика, а тільки перелічимо назви видань, поданих за їх видами, специфікою та проблематикою (зокрема, розділ 7 - «Резонансні акції українців в оцінці преси» (с. 437-468).

Аналіз газетної журналістики (розділ 3) дає змогу осмислити такі видання, як «Наш Клич», «Український Клич», «Українська думка», «Вісник Української Державницької Думки», «Думки», «Українська Консервативна Думка», «Вісник» (с. 147222). У розділі 4, присвяченому журнальній журналістиці, описано «Голос Молоді», «Визвольний Шлях», «Авангард», «Юні Друзі», «Сурмач», «Наша Церква», «Відомості єпархіального Управління УАПЦ у Великій Британії» (с. 223-332).

П'ятий розділ Микола Тимошик присвятив радійній журналістиці, зокрема радіостанціям «Голос Америки» та «Бі-Бі-Сі», питанням української мови на радіо («Рух за українське радіо») й питанням контенту радіопрограм, контролю за його змістом (с. 333-352).

У шостому розділі (про англомовну журналістику - с. 353-456) зроблено скрупульозний аналіз таких часописів та бюлетенів: «The Ukraine» («Україна»), «Ukrainian Bureau Bulletin» («Бюлетень Українського Бюро»), «The Investigator» («Дослідник»), «Ukrainian Bulletin» («Український Бюлетень»), преси Центрального українського допомогового бюро в Лондоні: «Refugee» («Скиталець»), «Refugee News» («Скитальські Вісті»), «Ukrainian Press Service» («Українська Пресова Служба»), «Ukrainian Information Service» («Українська Інформаційна Служба» - тут співпрацював ідеолог українського націоналізму Дмитро Донцов), «Ukrainian Observer» («Український Спостерігач»), а також видання «The Ukrainian Review» («Український Огляд»), яке виходило на постійній основі з 1955 по 1992 р.

У сьомому розділі, присвяченому резонансним акціям українців в оцінці преси, проф. Микола Тимошик аналізує, зокрема, тексти, що стосуються дискримінаційного рішення уряду, що було відмінене зусиллями українців («...через кілька днів після підписання уряд відкликав свою дискримінаційну, щодо українців, постанову. Різдвяне число «Української Думки» від 7 січня 1949 року виходить під шапкою такого заголовку: «Непрацездатні полонені залишаються у Великій Британії» $\left.{ }^{13}\right)$, суперечливості права на волю у вільному світі, консолідованої боротьби за рівні права, Українську справу у дзеркалі британської преси, оборони національної гідності українців (про захист дивізійників, про національний стяг України, про українських куркулів та брутальність московитів супроти українців). До слова, частково про це йшлося в монографії «Четвертована, але жива... Закордонна преса про політичні процеси в Україні напередодні Другої світової війни», зокрема в підрозділі «Усвідомлення необхідності незалежності України як предмет дискусій у британській пресі», надрукованої 1997 р. у Львові ${ }^{14}$.

\footnotetext{
${ }_{13}$ Тимошик, Микола (2021), Українська журналістика в діаспорі: Велика Британія, с. 449.

14 Житарюк, М. Г. (1997), Четвертована, але жива... с. 38-48.
} 
Рецензована книжка також упорядкована абревіатурним, іменним та предметним покажчиками. А доповнює її додаток «Українська книга і преса на чужині: Інтерв’ю професора Микола Тимошика лондонській газеті «Українська Думка» ${ }^{15}$.

Попри значну наукову і популяризаторську роботу в царині відтворення історії української журналістики в діаспорі ${ }^{16}$, ця праця, підготовлена на основі вивчення архівів та бібліотечних сховищ у Великій Британії, давно очікувана в українському пресознавстві, суттєво його доповнює, місцями відкриває нове прочитання. Водночас сподіваюся й на те, що, враховуючи сучасні реалії, Микола Степанович невдовзі підготує й електронну версію, нехай і скорочену, для розміщення в інтернеті. На мою думку, наявність електронного варіанта монографії «Українська журналістика в діаспорі: Велика Британія» значно посприяла б популяризації преси української діаспори у Великобританії.

\section{СПИСОК ЛІТЕРАТУРИ}

1. Животко, Аркадій (1989-90), Історія украӥнської преси, Український ТехнічноГосподарський Інститут, Мюнхен, 334 с.

2. Животко, Аркадій (1999), Історія української преси (Упор., авт. передм. і приміт. M. Тимошик, Наша культура і наука, Київ, 362 с.

3. Житарюк, М. Г. (1997), Четвертована, але жива... Закордонна преса про політичні процеси в Украӥні напередодні Другої світової війни (монографія), За вільну Україну, Львів, 128 с.

4. Ніщеменко, К., Зозуля, Я. (1947), Правила, програми та пляни навчання, Регенсбург, 1947, с. 110. У кн.: Тимошик, Микола (2021), Украӥнська журналістика в diacnopi... C. 52.

5. Пекарська, Людмила (2016), «Українська книга і преса на чужині: Інтерв’ю професора Микола Тимошика», Украӥнська Думка, 2 квіт., с. 9, 14.

6. Сірополко, Степан (1946), Основи журналізму. Курс лекиії, Регенсбург, 57 с.

7. Тимошик, Микола (2021), Українська журналістика в діаспорі: Велика Британія (монографія), Наша культура і наука, Київ, 512 с.

8. Шуль, Андрій (1972), «За катедру журналістики при УВУ», Український журналіст. Ч. 9, с. 38-39.

\section{REFERENCES}

1. Zhyvotko, Arkady (1989-90), Geschichte des Ukrainischen Zeitungswesens, Ukrainisches Technisch-Wirtschaftliches Institut, München, $334 \mathrm{~S}$.

2. Zhyvotko, Arkady (1999), Geschichte des Ukrainischen Zeitungswesens (Compiler, Autor des Vorworts und Notizen M. Tymoshyk), Unsere Kultur und Wissenschaft, Kiew, $362 \mathrm{~s}$.

\footnotetext{
${ }^{15}$ Пекарська, Людмила (2016), «Українська книга і преса на чужині...», 2 квіт. С. 9, 14.

16 Див.: Основні праці автора з історії, теорії і практики української журналістики і книговидання на чужині у кн.: Тимошик, Микола (2021), Українська журналістика в діаспорі: Велика Британія, с. 507-510.
} 
3. Zhytariuk, M. H. (1997), Chetvertovana, ale zhyva... Zakordonna presa pro politychni protsesy v Ukraini naperedodni Druhoi svitovoi viiny (monohrafiia), Za vilnu Ukrainu, Lviv, $128 \mathrm{~s}$.

4. Nishchemenko, K., Zozulia, Ya. (1947), Pravyla, prohramy ta pliany navchannia, Rehensburh, 1947, s. 110. U kn.: Tymoshyk, Mykola (2021), Ukrainska zhurnalistyka v diaspori... S. 52.

5. Pekarska, Liudmyla (2016), «Ukrainska knyha i presa na chuzhyni: Interviu profesora Mykola Tymoshyka», Ukrainska Dumka, 2 kvit., s. 9, 14.

6. Siropolko, Stepan (1946), Osnovy zhurnalizmu. Kurs lektsii, Rehensburh, 57 s.

7. Tymoshyk, Mykola (2021), Ukrainska zhurnalistyka v diaspori: Velyka Brytaniia (monohrafiia), Nasha kultura i nauka, Kyiv, 512 s.

8. Shul, Andrii (1972), «Za katedru zhurnalistyky pry UVU», Ukrainskyi zhurnalist, Ch. 9, s. 38-39.

\title{
UKRAINIAN JOURNALISM IN GREAT BRITAIN
}

\author{
Maryan Zhytaryuk \\ Ivan Franko National University of Lviv, \\ General Chuprynka street, 49, 79044, Lviv, Ukraine, \\ e-mail:marvan.zhytaryuk@lnu.edu.ua \\ https://orcid.org/0000-0002-5690-5701
}

Professor M. Zhytaryuk's review is about a book scientific novelty - a monograph by Professor M. Tymoshyk «Ukrainian journalism in the diaspora: Great Britain. Monograph. K.: Our culture and science, 2020. 500 p. - il., Them. pok., resume English, German, Polish.».

Well-known scientist and journalism critic, Professor M. S. Tymoshyk, wrote a thorough work, which, in terms of content, is a combination of a monograph, a textbook and a scientific essay. This book can be useful for both students and practicing journalists or anyone interested in the history of the Ukrainian diaspora, Ukrainian journalism and Ukrainian culture.

The author dedicated his work to Stepan Yarmus from Winnipeg, Canada - archpriest, journalist, editor, professor. As the epigraph to the book were taken the words of Ivan Bagryany: «Our press, born under the sword of Damocles of repatriation», not only survived and survived to this day, but also showed a brilliant ability to grow and develop. It was shown that beggars that had come to the West without money at heart can and know how to act so organized. It was also an example of how a modern «enbolshevist» and «denationalized» by the occupier man person is capable of a combined mass action».

Key words: Mykola Tymoshyk, Ukrainian journalism in Great Britain, print media, radio press, mission of Ukrainian journalist abroad. 